Kryvko Yurij, Soguiko Yurij, Hot Iryna, Antonenko Yuliia, Baida Mariana, Kovalska Marta. Condition of pro-oxidant and antioxidant systems in guinea pigs' lungs under the condition of immobilization stress. Journal of Education, Health and Sport. 2021;11(05): 319-324. eISSN 2391-8306. DOI http://dx.doi.org/10.12775/JEHS.2021.11.05.033

https://apcz.umk.pl/czasopisma/index.php/JEHS/article/view/JEHS.2021.11.05.033

https://zenodo.org/record/5559664

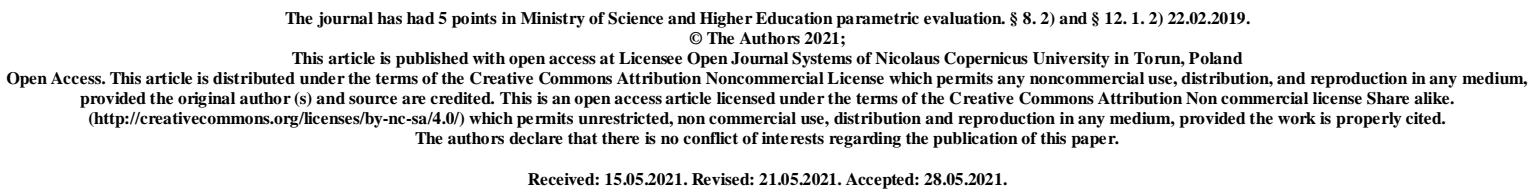

UDC: 616.24-002-008.6-056.3-092: 612.24.015.11

\title{
CONDITION OF PRO-OXIDANT AND ANTIOXIDANT SYSTEMS IN GUINEA PIGS' LUNGS UNDER THE CONDITION OF IMMOBILIZATION STRESS
}

\author{
Yurij Kryvko" ${ }^{1}$, Yurij Soguiko ${ }^{1}$, Iryna Hot' ${ }^{1}$, Yuliia Antonenko', Mariana Baida, \\ Marta Kovalska
}

\author{
Danylo Halytsky Lviv National Medical University, Lviv \\ ${ }^{1}$ Andrei Krupynskyi Lviv Medical Academy, Lviv \\ dr.kowalska.marta@gmail.com
}

\section{Abstract}

We have investigated the results of alterations in indices of pro-oxidant (conjugated diene and malondialdehyde) and antioxidant (superoxide dismutase, ceruloplasmin, catalase) systems in guinea pigs' lungs under the conditions of immobilization stress. The experiment was conducted on 40 female guinea pigs weighing $0.18-0.20 \mathrm{~kg}$. The animals were divided into 4 groups, each contained 10 guinea pigs: I - intact guinea pigs (control), II-guinea pigs with model of IS on $1^{\text {st }}$ day of experiment; $\amalg-$ animals on $2^{\text {nd }}$ day of experiment;IV- group of animals on $34^{\text {th }}$ day of experimental model of IS.

The results of our experimental work showed a significant accumulation of lipid peroxidation products in the lung`s tissure in different periods (on $1^{\text {st }}, 2^{\text {nd }}$ and $34^{\text {th }}$ days) of immobilization stress. The state of antioxidant defence was characterized by moderate decrease of inzymes activity (superoxide dismutase, catalase and ceruloplasmin). disorders of balance between pro-oxidant and antioxidant systems couse oxidative stress development. 


\section{Key words: immobilization stress; peroxide lipid oxidation; antioxidant system.}

\section{Introduction}

Stress interferes of inflammation and is considered like the most important factor in systemic adaptation under local answer in extraprdinary conditions.

Chronic stress leads to development of secondary immunodeficiency states which may couses cancer, autoimmune, infectious diseases, formation or exacerbation of chronic pathology. Limitation of aggressive factors' action contributs to restoration of immune responce [1].

Nowodays, stress is seen as a non-specific reaction of an organism that occurs on the action of external and internal stimuli and is realized as a necessary link of the individual adaptation of the organism to the environment. The development of immobilization stress is accompanied by the activation of proteolytic systems, peroxide lipid oxidation, decreases of antiproteinase and antioxidant potential, and the involvement of central and peripheral regulatory mechanisms $[2,3]$.

The causes of this disease are already known, but the pathogenetic mechanisms of its formation have not yet been fully understood. However, the changes in the pro-oxidant and antioxidant systems in the lungs under the condition of immobilization stress is not described enough. The action of various aggressive factors is often combined, causing a stressful reaction in the body.

Under the influence of stressors, at the same time, significant structural changes in the lungs occure. That leads to development of variety of pathologies $[4,5]$.

The aim of the research was to study lipid peroxidation processes and the condition of antioxidant protection in guinea pigs' lungs under the conditions of immobilization stress (IS).

\section{Materials and methods of investigation}

All experiments on laboratory animals were conducted following the principles of bioethics according to the regulations of European Convention for the protection of vertebrate animals used for experimental and other scientific purposes (Strasbourg, 1986), European Union Directive 2010/63/EU, Law of Ukraine № 3447-IV “On protection of animals from cruel treatment", general ethic principles of experiments on animals, approved by the first national congress of Ukraine on bioethics (2001).

The experiment was conducted on 40 female guinea pigs weighing $0.18-0.20 \mathrm{~kg}$. The animals were divided into 4 groups, each contained 10 guinea pigs: I - intact guinea pigs 
(control), II-guinea pigs with model of IS on $1^{\text {st }}$ day of experiment; $\amalg-$ animals on $2^{\text {nd }}$ day of experiment;IV- group of animals on $34^{\text {th }}$ day of experimental model of IS.

Immobilization stress was imitated by P.D.Horizontov method [6]. Later, the animals were decapitated; the level of LOPs and activity of antioxidant system enzymes were detected in lung homogenate on the $1^{\text {st }}, 2^{\text {nd }}, 34^{\text {th }}$ days of stress activity. The content of conjugated dienes was determined by the method of V.B. Havrylov and M.I. Myshkorudina [7], malondialdehyde (MDA) - by E.N. Korobeinikov method [8], superoxide dismutase activity - by R.Fried method [9], catalase activity - by R. Holmes [10], and ceruloplasmin - by V.H. Kolb and V.S. Kamyshnikov method [11].

All digital results were statistically processed using arithmetical mean (M), margin of error of arithmetical mean (m), and Student's criterion " $t$ ". The calculations were performed using means of statistical and graphic analysis of electron tables Microsoft Excel (Microsoft office programs). Statistically reliable were the results with $\mathrm{P} \leq 0.05$.

\section{Results of investigation and their discussion}

Changes of functional state of pro- oxidant and antioxidant systems we determinated by means of conjugated dienes and malondialdehyde content. Activity of antioxidant defence was estimated according such indicators like superoxide dismutase, catalase and ceruloplasmin.

The results of our experimental investigations showed a significant accumulation of lipid peroxidation products in different periods of immobilization stress.

In particular, increase in conjugated dienes in the lungs was observed on the $1^{\text {st }}, 2^{\text {nd }}$ and $34^{\text {th }}$ days of IS by $135,12 \%(p<0,05)$ тa $100,91 \%(p<0,05)$ and $33,81 \%(p<0,05)$ respectively, in comparison with the control.

Investigation of another marker of lipoperoxidational processes- malondialdehyde in the lungs give possibility to reveale it`s elevation. Thus, a gradual increasing of MDA level in the lungs was recorded on the $1^{\text {st }}, 2^{\text {nd }}$ and $34^{\text {th }}$ days under the conditions of stress development by на $80,53 \%(p<0,05), 70,29 \%(p<0,05)$ та 22,69\% $(\mathrm{p}<0,05)$ respectively, in comparison with the data of intact animals.

Thus, learning of indicators of prooxidant system (conjugated dienes and malondialdehyde) in dynamic of immobilization stress have showed increasing of it`s level in the lungs reaching its peak on the $34^{\text {th }}$ day of the experiment (Fig.1). Activation of lipid oxidation processes couses intensive formation of free radicals and plays an important role in tissure damage. 
The state of antioxidant defence under IS was characterized with changes of inzymes activity (superoxide dismutase, catalase and ceruloplasmin) in the lungs. The activity of superoxide dismutase was decreasing during all period of experiment, on the $1^{\text {st }}, 2^{\text {nd }}$ and $34^{\text {th }}$ days by $23,27 \%(\mathrm{p}<0,05) 22,57 \%(\mathrm{p}<0,05)$ та $13,86 \%(\mathrm{p}<0,05)$ respectively, in comparison with the control indices.

Definitely, correctly estimation of prooxidant system state is impossible just according one indicator. For complete characteristic we used also activity of catalase and ceruloplasmin in the lungs under the immobilization stress.

Moderate reduction of catalase activity in the lungs was observed on $1^{\text {st }}, 2^{\text {nd }}$ and $34^{\text {th }}$ days the by $34,17 \%(\mathrm{p}<0,05), 27,78 \%(\mathrm{p}<0,05)$ та $11,13 \%$ respectively, in comparison with the phisyologycal norm.

The changes similar to catalase occurred with ceruloplasmin. In particular, a moderate depression of ceruloplasmin activity in the lungs was observed. It demonstrates results which we reseaved. Under the condition of IS development on $1^{\text {st }}$ and $2^{\text {nd }}$ days of the experiment decreasing of ceruloplazmin activity was by $33,49 \%(p<0,05)$ та $26,02 \%(p<0,05)$. Further, the activity of this enzyme in the lungs decreased significantly by $10.11 \%(p<0.05)$ against the values of the intact group.

Results which were reseaved pointed on exhaustion of antioxidant system (Fig.1).

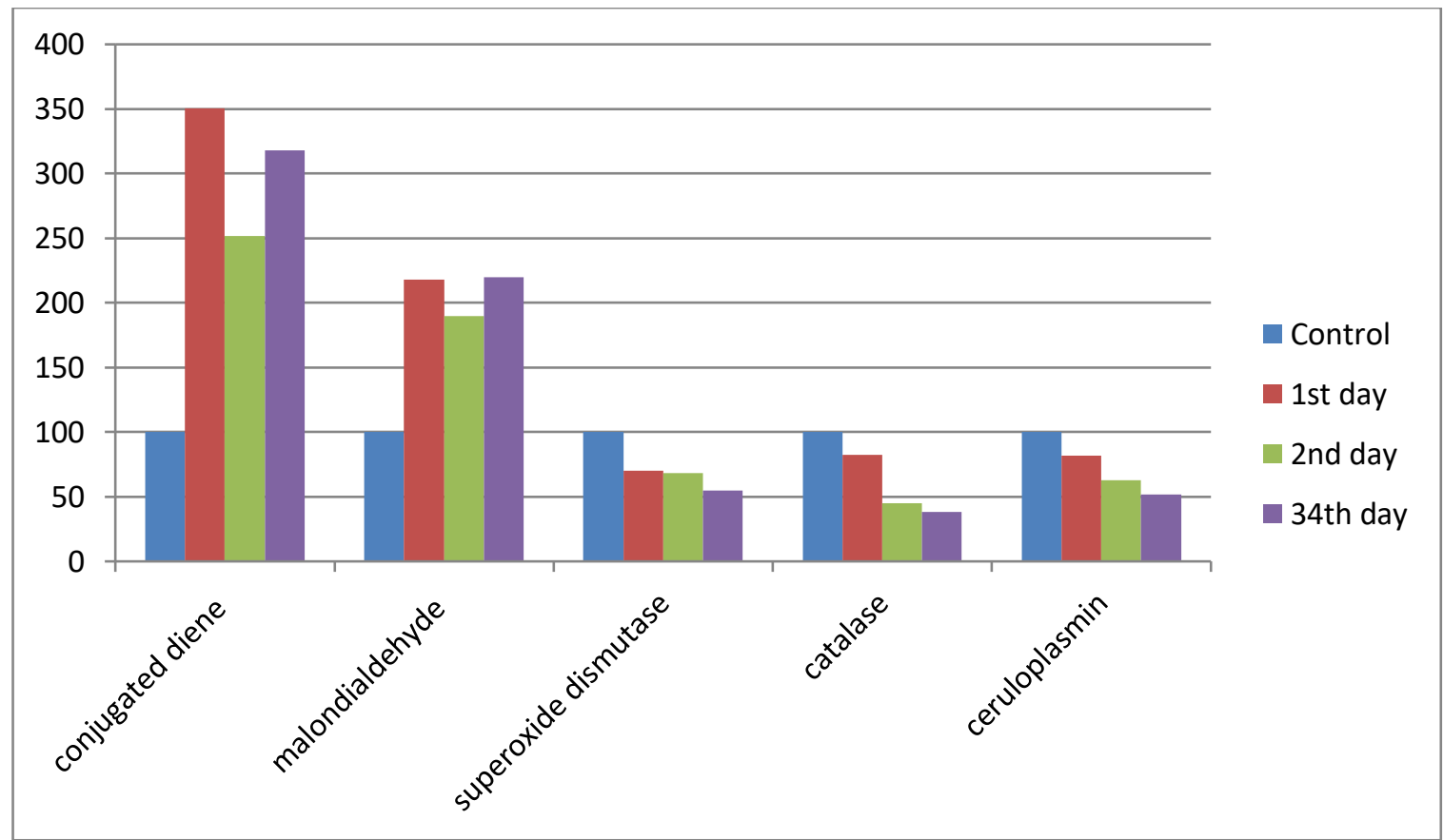

Fig.1. Condition of pro-oxidant and antioxidant systems in the animals' lungs under the conditions of IS (in \% of control) 
Conclusions. The obtained results indicate that a gradual accumulation of lipid peroxidation products occurs under the conditions of immobilization stress, reaching its peak on the $34^{\text {th }}$ day of the experiment. In its turn, significant decreasing of the superoxide dismutase, catalase and ceruloplasmin activity on $1^{\text {st }}, 2^{\text {nd }}$ and $34^{\text {th }}$ days days of the experiment, which indicated the depletion of antioxidant defense during the development of this experimental IS model. It point out on disturbing of balance between pro- oxidant and antioxidant system during immobilization stress formation and gives possibility to making of new experimental researches.

\section{References}

1. Stress cardiomyopathy after intravenous administration of catecholamines and beta-receptor agonists. J. Abraham, J. O. Mudd, N. K. Kapur [et al.] J. Am. Coll. Cardiol. 2009; 53(15): 1320-1325.

2. Post-traumatic stress. The mechanisms of trauma. D. Guerreiro, B. Brito, J. L. Bartista et al Acta Med. Port. 2007; 20(4): 347-354.

3. L. Lu, M. T. Quinn, Y. Sun Oxidative stress in the infarcted heart : role of de novo angiotensin II production. Biochemical and Biophysical Research Communications. 2004; 325(3): 943-951.

4. Khasky A.D., Smith J.C. Stress, relaxation states, and creativity. Percept. Mot. Skills. 2000,88 (22), 409416.

5. Karanth J., Jeevaratnam K. Oxidative stress and antioxidant status in rat blood, muscle: effect of dietary lipid, carnitine and exercise bit. J. Vitam. Nutr. Res. 2005;75(5):333339.

6. Gorizontov PD, Belousova OI, Fedotov MI. Stress i sistema krovi. M.: Meditsina. 1983: 338 s.[Rusian]

7. Gavrilov A.B., Myshkorudnaya M.I. Spektrofotometricheskoye opredeleniye soderzhaniya gidroperekisey lipidov v plazme. Laboratornaya diagnostika ishemicheskoy bolezni serdtsa, - K.: Zdorov'ya, 1989,170-171. [Rusian]

8. Korobeynikov E.N. Modifikatsiya opredeleniya produktov POL v reaktsii $\mathrm{s}$ tiobarbiturovoy kislotoy Lab. delo 1989,7,8-10. [Rusian]

9. Fried, R. (1975). Enzymatic and non-enzymatic assay of super oxide dismutase. Biochemie, (57), 65, 657-660.

10. Holmes, R. \& Masters, C. (1970). Epigenetic interconversions of the multiple forms of mouse liver catalase. FEBS Lett.,(11), 1, 45-48. 
11. Kolb VG, Kamyshnikov VS. Opredeleniye aktivnosti tseruloplazmina v krovi. Spravochnik po klinicheskoy khimii. Minsk: Belarus'. 1982: 290-291. [Rusian] 